\title{
Maize response to time of nitrogen application and planting seasons
}

\author{
Parbati Adhikari*, Bandhu Raj Baral and Jiban Shrestha \\ National Maize Research Program, Rampur, Chitwan, Nepal \\ *Corresponding author email: paru.adhikari@yahoo.com
}

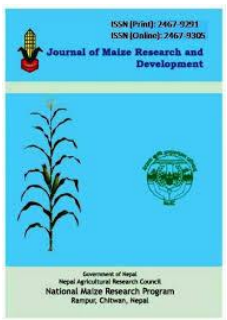

Received: September 2016; Revised: October 2016; Accepted: November 2016

\begin{abstract}
Nitrogen $(\mathrm{N})$ response by maize differs due to growing seasons, growth stages, duration and growing domain as $\mathrm{N}$ losses is higher due to leaching as well as volatilization. Objective of this study was to know the response of split applications of $\mathrm{N}$ and growing seasons on maize under Chitwan environments. Field experiments were conducted for two consecutive years at the research field of NMRP Rampur during the winter, spring, and summer seasons of 2012/013 and 2013/014. Experiments were laid out in factorial randomized complete block design with four replications for all the seasons. Early maturing maize genotype Arun-1 EV was used for the experiments. Five splits of recommended dose of $\mathrm{N}$ were tested. Grain yield, days to flowering, plant height, ear height, kernel rows per ear, no. of kernels per row, ear length and thousand grain weight significantly differed due to growing seasons and split applications of $\mathrm{N}$. Significantly higher grain yield $\left(3911 \mathrm{~kg} \mathrm{ha}^{-1}\right)$ was obtained with the application of $30 \mathrm{~kg} \mathrm{~N} \mathrm{ha}^{-1}$ each at 30, 45, 60, and 75 days after sowing as compared to control $\left(2801 \mathrm{~kg} \mathrm{ha}^{-1}\right)$. Regarding the growing seasons, highest grain yield was obtained in winter $\left(4393 \mathrm{~kg} \mathrm{ha}^{-1}\right)$ followed by spring $\left(3791 \mathrm{~kg} \mathrm{ha}^{-1}\right)$ and summer $\left(2468 \mathrm{~kg} \mathrm{ha}^{-1}\right)$ season, respectively. Results of these studies revealed that four splits of $\mathrm{N}$ viz. application of $30 \mathrm{~kg} \mathrm{~N}$ each at 30, 45, 60, and 75 days after sowing respectively, would be more economical to minimize $\mathrm{N}$ losses from the soil and efficient use of $\mathrm{N}$ at critical growth and development stages of maize.
\end{abstract}

Keywords: Leaching, maize, nitrogen, seasons

Correct citation: Adhikari, P., Baral, B.R., \& Shrestha, J. (2016). Maize response to time of nitrogen application and planting seasons. Journal of Maize Research and Development, 2(1): 83-93, doi: http://dx.doi.org/10.3126/jmrd.v2i1.16218

\section{INTRODUCTION}

Yield is a function of genotypes, environments and crop managements. Fertilizer management is crucial for maize cultivation (Baral et al., 2015). Among the fertilizers, $\mathrm{N}$ is very important because this element is responsible on major activities for growth and development of maize crop (Jat et al., 2013). Maize being the heavy feeder crop, a balanced dose of organic and inorganic application of fertilizer is needed for increased productivity. Under abundant water condition, the crop growth and yield greatly depend on supply of soil $\mathrm{N}$ and its proper 
management (Saseendran et al., 2004). Fertilizer N applied to crop is subjected to many chances; a portion of the $\mathrm{N}$ will remain in the soil, some may be lost to the air, surface water, and/or ground water (Jat et al., 2013). Sherchan et al., (2007) also reported that response of $\mathrm{N}$ and its application time to maize differs due to genetic characters, growing season (winter, spring, and summer), maturity period (early and full season), and growing domain (mountain/hill and Terai) as losses of $\mathrm{N}$ takes place due to several reasons like leaching as well as volatilization from most of the soils. The result from a study about $\mathrm{N}$ application timing on maize conducted at NMRP research farm revealed that the $\mathrm{N}$ content of soil was reported to be in the range of 0.068 to 0.105 and suggested to apply $100 \mathrm{~kg} \mathrm{~N} \mathrm{ha}^{-1}$, half as basal application and the other half as top dressing at knee height stage and tasseling stage with 2 subsequent irrigations so that it could help increase crop productivity in Chitwan soil condition (Adhikary et al., 2004). The recent data published by the Ministry of Nepal showed that most of the farmers of Nepal do not apply chemical fertilizer in the maize crop as per recommendation (ABPSD, 2014). In general, they apply only urea if possible and available in the market. The farmers of outreach sites of NMRP apply around $30 \mathrm{~kg} \mathrm{~N} \mathrm{ha}^{-1}$ (NMRP, 2014) once at knee high stage only. Objective of this study was to know the response of different splits and application timings of $\mathrm{N}$ for different growing seasons at Chitwan environments. The proper combination of nitrogen application timing and planting season are very important for higher grain yield of maize. Therefore these studies were conducted to identify that combination.

\section{MATERIALS AND METHODS}

\section{Experimental site}

The experiments were carried out at the research field of National Maize Research Program (NMRP) Rampur, Chitwan during the winter, spring, and summer seasons of 2012/013 and $013 / 014$. The experimental site was located at $27^{\circ} 39^{\prime}$ Northern Latitude, $84^{0} 21^{\prime}$ Eastern Longitude and at an elevation of 185 meter above the sea level (NMRP, 2014). Maize can be grown throughout the year in Chitwan district and can also be grown in other similar environments (KC et al., 2015). Early maturing maize Arun-1 EV (now released in the name of Arun-3 for general cultivation) was selected for this experiment for both the years and all the seasons.

\section{Maize variety}

Early maturing maize variety (Arun-1 EV) was selected for the study. Arun-1EV was developed/selected from Arun-1 which is also the early maturing maize genotype. Arun-1 EV has yield potential up to $5,000 \mathrm{~kg} \mathrm{ha}^{-1}$. Kernel of this genotype is white and flint type. It has open leaves and shorter plant height. Stem is robust and has no lodging problem .The vigorous growth, early maturing habit, good test and good husk cover are the main traits of Arun-1 EV.

\section{Field trial management and treatment combination}

The soil of the experimental field of NMRP Rampur is sandy soil and $\mathrm{N}$ leaching is the major problem (Adhikary et al., 2004). Therefore, to know the effect of $\mathrm{N}$ losses on maize yield and yield attributing characters, following treatment combinations were tested;

T1 - $60 \mathrm{~kg} \mathrm{~N} \mathrm{ha}^{-1}$ basal application and $60 \mathrm{~kg} \mathrm{~N} \mathrm{ha}^{-1}$ at $45 \mathrm{DAS}$ 
T2 - $40 \mathrm{~kg} \mathrm{~N} \mathrm{ha}^{-1}$ basal application, $40 \mathrm{~kg} \mathrm{~N} \mathrm{ha}^{-1}$ each at 45 and 60 DAS

T3 - $30 \mathrm{~kg} \mathrm{~N} \mathrm{ha}^{-1}$ basal application, $30 \mathrm{~kg} \mathrm{~N}$ ha $^{-1}$ each at 30, 45, and $60 \mathrm{DAS}$

T4 $-30 \mathrm{~kg} \mathrm{~N} \mathrm{ha}^{-1}$ each at 30, 45, 60, and 75 DAS

T5 - Control (FYM 10 ton per hectare with no chemical fertilizers)

The factorial randomized complete block design along with four replications was used for all the seasons and years. Maize was planted in six rows of five-meter-long plot and spacing were kept $25 \mathrm{~cm}$ for plant to plant while $75 \mathrm{~cm}$ for row to row. Therefore, the plot size was 13.5 meter square for each treatment. Before maize sowing, soil samples were taken from the experimental field from the top layer $(15 \mathrm{~cm}$ and $30 \mathrm{~cm}$ depth) of the soil and $\mathrm{N}$ content, $\mathrm{pH}$, and organic matter content were analyzed at the soil laboratory of NMRP, Rampur. Recommended dose of phosphorous $\left(60 \mathrm{~kg} \mathrm{ha}^{-1}\right)$ and potash $\left(40 \mathrm{~kg} \mathrm{ha}^{-1}\right)$ were applied before maize sowing on each research plot. For farm yard manure (FYM), all amount was applied before final land preparation. Normal tillage practices were followed. Other crop management practices were similar to normal maize cultivation practices. The seed sowing dates for 2012/013 were 27 September, 19 February, and 27 May respectively. Similarly in 2013/014 plantings were done on 28 September, 21 February, and 15 June, respectively.

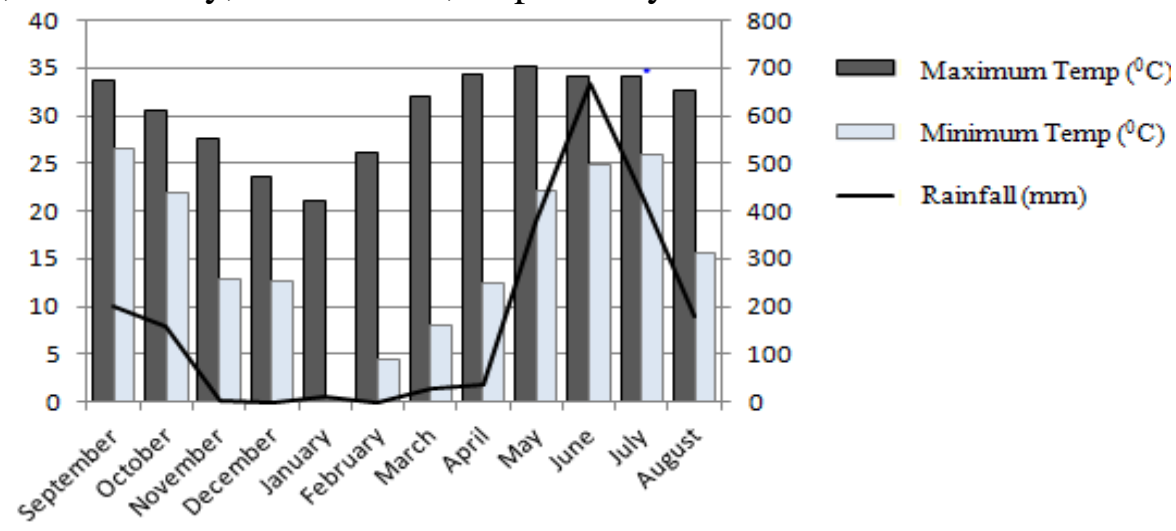

Figure 1. Weather data of the maize during its growing period at Rampur, Chitwan 2012/013.

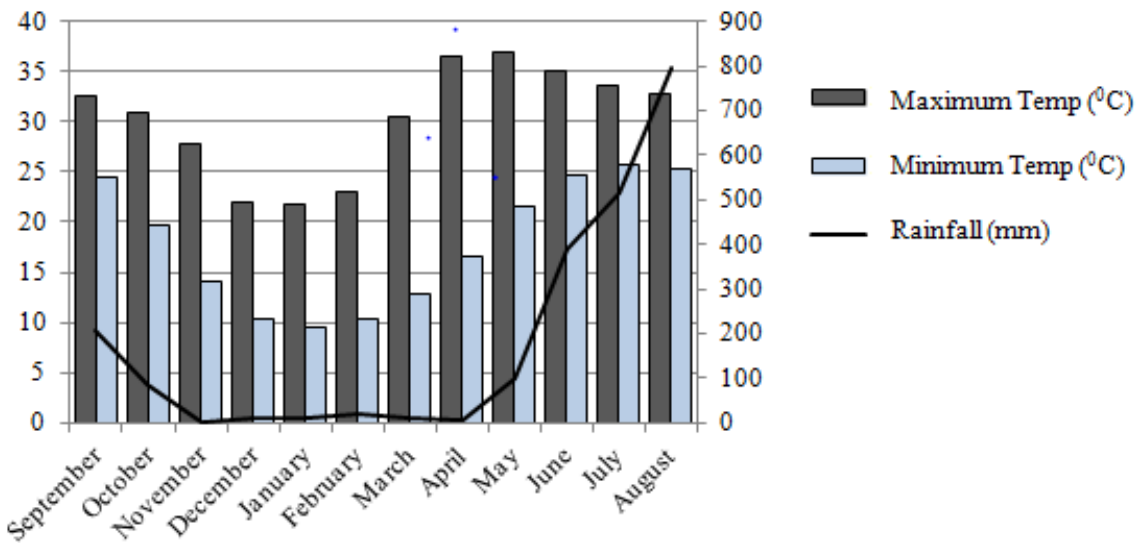

Figure 2. Weather data of the maize during its growing period at Rampur, Chitwan 2013/014.

Details of the weather data of the planting seasons of 2012/2013 and 2013/2014 is presented in the figure 1 and 2. 
Grain yield was estimated using formula adopted by Carangal et al. (1971) \& Shrestha et al. (2015) by adjusting the grain moisture at $15 \%$ and converted to the grain yield kg per hectare. Similarly, Data were analyzed by using CROP-STAT computer program applying 5\% significance level.

\section{Soil analysis report}

\section{RESULTS AND DISCUSSION}

Soil analysis report from the samples taken before maize sowing of the two consecutive years revealed that the average organic matter $(\mathrm{OM})$ content of all the plots were $2.16 \%$ (ranged from 1.99 percent to 2.5) which is considered to be good for crop growth and development. Similarly, total nitrogen content in the soil ranged from 0.099 to 0.125 .In a study conducted at NMRP research farm, the $\mathrm{N}$ content of soil was reported to be in the range of 0.068 to 0.105 (Sherchan, 2004). The soil analysis result from both the years indicated that the research plots were quite uniform and were almost homogeneous in soil fertility.

\section{Crop response to $\mathbf{N}$}

$\mathrm{N}$ often varies with the weather conditions during the crop growth and development, therefore the relationship between $\mathrm{N}$ supply, crops demand and weather conditions is important for development of successful $\mathrm{N}$ management strategies (Wolkowsky et al., 2015). They also recommended to provide $\mathrm{N}$ closer to the optimum uptake time (i.e. knee height stage through grain filling stage) in multiple applications to minimize pre-plant and seasonal $\mathrm{N}$ loss. Jat et al., (2013) reported that sequential applications of $\mathrm{N}$ just prior to planting with starter fertilizer at a rate of $30 \mathrm{~kg} \mathrm{~N} \mathrm{ha}^{-1}$ and split applications at knee height stage, and at the time of flowering stage can be an effective $\mathrm{N}$ delivery system.

Table 1. ANOVA table for grain yield and other agronomical parameters as influenced by different $\mathbf{N}$ application timings and maize growing seasons under Rampur, Chitwan conditions during 2012/13 and 2013/14.

\begin{tabular}{|c|c|c|c|c|c|c|c|c|c|}
\hline $\begin{array}{l}\text { Source of } \\
\text { Variation }\end{array}$ & $\begin{array}{l}\text { Tasseling } \\
\text { (days) }\end{array}$ & $\begin{array}{l}\text { Silking } \\
\text { (days) }\end{array}$ & $\begin{array}{l}\text { Plant } \\
\text { height } \\
(\mathrm{cm})\end{array}$ & $\begin{array}{l}\text { Ear } \\
\text { height } \\
(\mathrm{cm})\end{array}$ & $\begin{array}{l}\text { Ear } \\
\text { length } \\
(\mathrm{cm})\end{array}$ & $\begin{array}{l}\text { Kernel } \\
\text { rows } \\
\text { lear } \\
\text { (no.) }\end{array}$ & $\begin{array}{l}\text { No. of } \\
\text { kernel } \\
\text { /row } \\
\text { (no.) }\end{array}$ & $\begin{array}{l}1000 \\
\text { grain } \\
\text { weight } \\
\text { (gram) }\end{array}$ & $\begin{array}{l}\text { Grain } \\
\text { yield } \\
\left(\mathrm{kg} \mathrm{ha}^{-1}\right)\end{array}$ \\
\hline 1. Season & $\mathrm{P}<0.01$ & $\mathrm{P}<0.01$ & $\mathrm{P}<0.01$ & $\mathrm{P}<0.01$ & $\mathrm{P}<0.01$ & $\mathrm{P}<0.01$ & $\mathrm{P}<0.01$ & $\mathrm{P}<0.01$ & $\mathrm{P}<0.01$ \\
\hline 2. Treatment (Trt) & $\mathrm{P}<0.01$ & $\mathrm{P}<0.01$ & $\mathrm{P}<0.01$ & $\mathrm{P}<0.01$ & $\mathrm{P}<0.01$ & $\mathrm{P}<0.01$ & $\mathrm{P}<0.01$ & $\mathrm{P}<0.01$ & $\mathrm{P}<0.01$ \\
\hline 3. Season $\times$ Trt & $\mathrm{P}<0.01$ & $\mathrm{P}<0.01$ & $\mathrm{P}<0.01$ & $\mathrm{P}<0.01$ & $\mathrm{P}<0.01$ & $\mathrm{P}<0.01$ & $\mathrm{P}<0.01$ & $\mathrm{P}<0.01$ & 0.16 \\
\hline 4. Yearx Season & 0.42 & 0.15 & 0.23 & 0.36 & 0.46 & 0.12 & 0.33 & 0.001 & 0.08 \\
\hline 5. Year $\times$ Trt & 0.37 & 0.39 & 0.33 & 0.51 & 0.90 & 0.70 & 0.57 & 0.004 & 0.60 \\
\hline 6. Year $\times$ Season $\times \operatorname{Trt}$ & 0.76 & 0.35 & 0.30 & 0.35 & 0.11 & 0.10 & 0.15 & $\mathrm{P}<0.01$ & 0.55 \\
\hline
\end{tabular}




\section{Days to tasseling and silking}

Significant difference $(\mathrm{P}<0.001)$ was observed for days to tasseling due to growing season, $\mathrm{N}$ application timings, and their interaction (Table 1). Same result $(\mathrm{P}<0.001)$ was found for days to silking as well (Table 1). Days to tasseling (49 day) and silking (54 day) was earliest in summer season planting followed by spring season (57 day tasseling and 61 day silking) and winter season planting (66 day tasseling and 73 day silking). Days to silking and tasseling was found late for winter planting compared to summer season planting. Regarding the days to tasseling and silking as influenced by $\mathrm{N}$ application timings, it ranged from 57 days after sowing (basal application of $60 \mathrm{~kg} \mathrm{~N} \mathrm{ha}^{-1}$ and $60 \mathrm{~kg} \mathrm{~N} \mathrm{ha}^{-1}$ at 45 days after sowing (DAS) to 61 DAS (Control i.e. application of 10 ton FYM ha ${ }^{-1}$ and no chemical fertilizers). It is obvious that the growth and development of maize is slower at cool season as compared to hot season planting and in general silking and tasseling occurs after the accumulation of approximately1135 growing degree units (GDU) (aganytime.com). The details of the tasseling and silking was presented in the Table 1,2, and 3 .

\section{Plant height and ear height}

Plant height and ear height significantly differed $(\mathrm{P}<0.001)$ due to growing season and $\mathrm{N}$ application timings (Table 1). The plant height varied in different seasons for the same variety. The interaction between growing season and $\mathrm{N}$ application timing was also found statistically significant $(\mathrm{P}<0.001)$ for both plant height and ear height. The plant height for summer $(151 \mathrm{~cm})$ and spring season $(150 \mathrm{~cm})$ was statistically at par however the plant and ear height significantly lower $(131 \mathrm{~cm})$ for winter season. Similarly, for ear height significantly tallest ear height was observed in summer season $(75 \mathrm{~cm})$, followed by spring season $(71 \mathrm{~cm})$, and winter season $(66$ $\mathrm{cm})$. Similarly, regarding the plant and ear height due to $\mathrm{N}$ application timings, it differed significantly. The tallest ear $(75 \mathrm{~cm})$ and plant height $(153 \mathrm{~cm})$ was got with the application of 30 $\mathrm{kg} \mathrm{N}$ ha $^{-1}$ each at 30, 45, 60, and 75 DAS, while the lowest ear height $(58 \mathrm{~cm})$ and lowest plant height $(119 \mathrm{~cm})$ were observed. A detail is presented in table 1, 2, and 3. Several research results revealed that plant and ear height differs due to growing seasons and environments. Similar findings were reported by Sangakkara et al., (2004) that plant height significantly differed due to plant population densities and growing environment. From a preliminary result conducted at NMRP, Rampur for maize, it is found that in rainy season, higher plant and ear height were found as compared to winter season (NMRP, 2015). It might be due to that plant gets lower sunlight because of cloudy days and plant goes up and up for light. Excess soil moisture would be another reason for higher plant height in rainy season as well. Similarly, the increase in plant height with more $\mathrm{N}$ splits would be due to supply of proper amount of $\mathrm{N}$ at different growth stages of maize and $\mathrm{N}$ promotes plant growth, increases the number and length of the internodes which resulted in progressive increase in plant height.

\section{Yield attributing characters}

Thousand grain weight, ear length, no. of kernel rows per ear, no. of kernels per row were found statistically significant $(\mathrm{P}<0.001)$ due to growing season and $\mathrm{N}$ application timings (table 1). Statistically, more bold grains, longer ear length, more no. of rows per ear, more no. of kernels per row were found in winter season plantings as compared to spring and summer season 
plantings (Figure 3, 4, 5, 6). It might be due to more accumulation of photosynthates for grain development. In summer and spring season due to higher temperature, lower rate of photosynthesis and high rate of respiration takes place resulted in lower accumulation of photosynthates as described by Hatfield and Prueger et al.(2015). In contrast, the temperature is lower in winter season that resulted in higher accumulation of photosynthate which caused for bold grains, longer ear length, more no. of ear rows, and kernels per ear as well. Similarly, almost similar results were found with more $\mathrm{N}$ splits as compared to lesser no. of $\mathrm{N}$ splits (OSU, 2016). Details of the research findings are presented in the following figures.

Table 2. Effect of different growing seasons on tasseling and silking of maize for the two consecutive years (2012/013 and 2013/014) at Rampur, Chitwan, Nepal

\begin{tabular}{|c|c|c|c|c|c|c|c|}
\hline \multirow[t]{2}{*}{$\mathrm{SN}$} & \multirow{2}{*}{$\begin{array}{l}\text { Growing } \\
\text { Season }\end{array}$} & \multicolumn{2}{|c|}{ Tasseling (days) } & \multirow[t]{2}{*}{ Mean } & \multicolumn{2}{|c|}{ Silking (days) } & \multirow[t]{2}{*}{ Mean } \\
\hline & & $2012 / 013$ & $2013 / 014$ & & $2012 / 013$ & $2013 / 014$ & \\
\hline 1 & Spring & 57 & 58 & 58 & 63 & 68 & 65 \\
\hline 2 & Winter & 64 & 68 & 66 & 65 & 75 & 70 \\
\hline \multirow[t]{5}{*}{3} & Summer & 50 & 48 & 49 & 52 & 56 & 54 \\
\hline & Mean & 57 & 58 & 58 & 60 & 66 & 63 \\
\hline & F-test & $* *$ & $* *$ & & $*$ & $* *$ & \\
\hline & $\mathrm{LSD}_{0.05}$ & 1.23 & 1.98 & & 2.1 & 1.3 & \\
\hline & $\mathrm{CV} \%$ & 3.4 & 3.8 & & 2.9 & 3.5 & \\
\hline
\end{tabular}

Table 3. Effect of growing seasons on plant height and ear height of maize for the two consecutive years (2012/013 and 2013/014) at Rampur, Chitwan, Nepal

\begin{tabular}{|c|c|c|c|c|c|c|c|}
\hline \multirow[t]{2}{*}{ SN } & \multirow{2}{*}{$\begin{array}{l}\text { Growing } \\
\text { Season }\end{array}$} & \multicolumn{2}{|c|}{ Plant height $(\mathrm{cm})$} & \multirow[t]{2}{*}{ Mean } & \multirow{2}{*}{$\begin{array}{l}\text { Ear height }(\mathrm{cm}) \\
2012 / 013\end{array}$} & \multicolumn{2}{|c|}{ Mean } \\
\hline & & $2012 / 013$ & $2013 / 014$ & & & 201 & \\
\hline 1 & Winter & 144 & 156 & 150 & 66 & 75 & 71 \\
\hline 2 & Spring & 127 & 135 & 131 & 58 & 73 & 66 \\
\hline \multirow[t]{5}{*}{3} & Summer & 149 & 153 & 151 & 62 & 83 & 73 \\
\hline & Mean & 140 & 148 & 144 & 62 & 77 & 70 \\
\hline & F-test & $* *$ & $*$ & & $*$ & $* *$ & \\
\hline & $\mathrm{LSD}_{0.05}$ & 4.03 & 4.27 & & 4.12 & 3.98 & \\
\hline & CV\% & 6.42 & 5.64 & & 5.89 & 6.01 & \\
\hline
\end{tabular}

Table 4. Effect of growing seasons on grain yield of maize for the two consecutive years (2012/013 and 2013/014) at Rampur, Chitwan, Nepal

\begin{tabular}{llccc}
\hline SN & Growing & \multicolumn{2}{c}{ Grain yield $\left(\mathrm{kg} \mathrm{ha}^{-1)}\right.$} & \multirow{2}{*}{ Mean } \\
\cline { 2 - 4 } & Season & $2012 / 013$ & $2013 / 014$ & \\
\hline 1 & Winter & 3352 & 4230 & 3791 \\
2 & Spring & 4251 & 4535 & 4393 \\
3 & Summer & 2689 & 2245 & 2467 \\
\hline & Mean & 3430 & 3670 & 3550 \\
& F-test & $*$ & $* *$ & \\
& LSD 0.05 & 567 & 613 & \\
& CV\% & 16.4 & 19.3 & \\
\hline
\end{tabular}



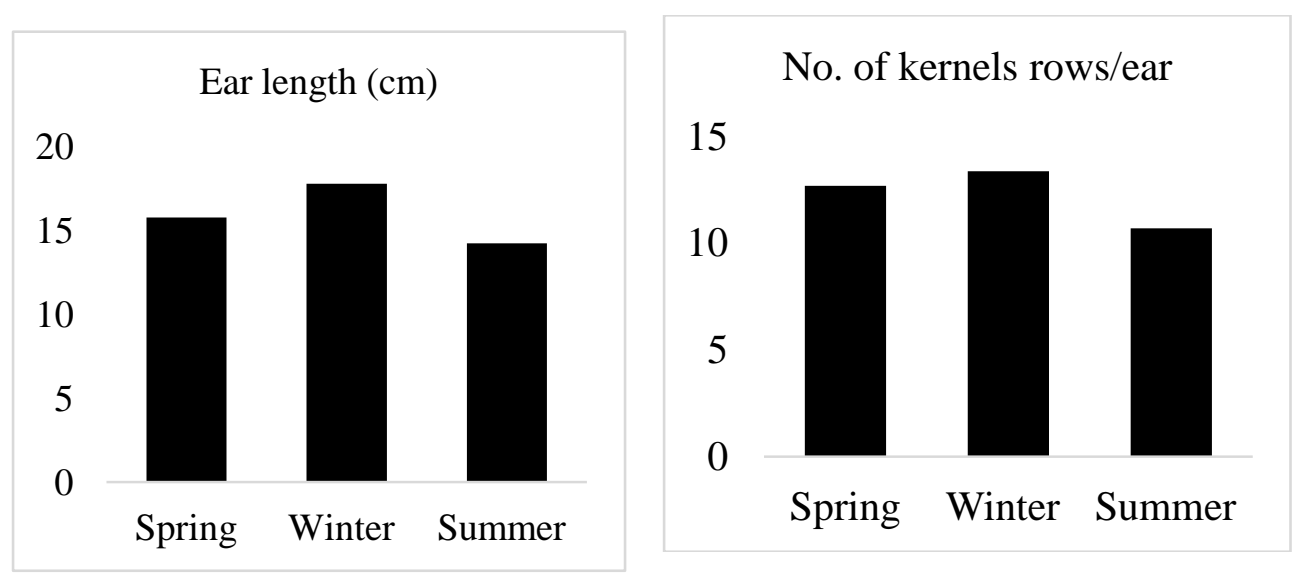

Figure 3. Combined response of growing seasons on ear length and no. of kernels rows per ear of maize for the two consecutive years (2012/013 and 2013/014) at Rampur, Chitwan, Nepal

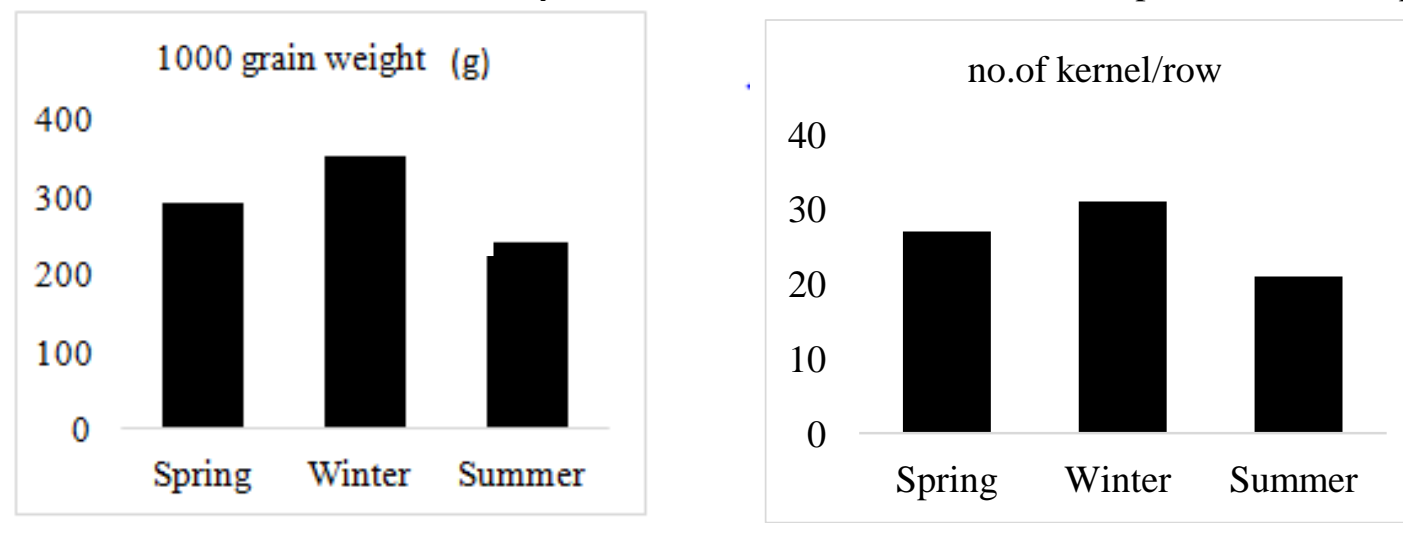

Figure 4. Combined response of growing seasons on thousand grain weight and no.of kernel per row of maize for the two consecutive years (2012/013 and 2013/014) at Rampur, Chitwan, Nepal

Table 5. Effect of different nitrogen application timings on tasseling and silking of maize for two consecutive years (2012/013 and 2013/014) at Rampur, Chitwan, Nepal

\begin{tabular}{|c|c|c|c|c|c|c|c|}
\hline \multirow[t]{3}{*}{$\begin{array}{l}\mathrm{S} \\
\mathrm{N}\end{array}$} & \multirow[t]{3}{*}{$\mathrm{N}$ application timings } & \multicolumn{2}{|c|}{$\begin{array}{l}\text { Tasseling } \\
\text { (days) }\end{array}$} & \multirow[t]{3}{*}{ Mean } & \multicolumn{2}{|c|}{$\begin{array}{l}\text { Silking } \\
\text { (days) }\end{array}$} & \multirow[t]{3}{*}{ Mean } \\
\hline & & 2012 & 2013 & & 2012 & 2013 & \\
\hline & & $/ 013$ & $/ 014$ & & $/ 013$ & $/ 014$ & \\
\hline 1. & $\begin{array}{l}60 \mathrm{~kg} \mathrm{~N} \mathrm{ha}^{-1} \text { basal application and } 60 \mathrm{~kg} \mathrm{~N} \mathrm{ha}^{-1} \text { at } \\
45 \text { DAS }\end{array}$ & 56 & 58 & 57 & 60 & 64 & 62 \\
\hline 2. & $\begin{array}{l}40 \mathrm{~kg} \mathrm{ha}^{-1} \text { basal application, } 40 \mathrm{~kg} \mathrm{ha}^{-1} \text { each at } 45 \\
\text { and } 60 \mathrm{DAS} \text {. }\end{array}$ & 55 & 59 & 57 & 60 & 64 & 62 \\
\hline 3. & $\begin{array}{l}30 \mathrm{~kg} \mathrm{ha}^{-1} \text { basal application, } 30 \mathrm{~kg} \mathrm{~N} \text { each at } 30 \text {, } \\
45 \text {, and } 60 \text { DAS }\end{array}$ & 56 & 57 & 57 & 61 & 61 & 61 \\
\hline 4. & $30 \mathrm{~kg} \mathrm{~N} \mathrm{ha}^{-1}$ each at $30,45,60$, and 75 DAS & 55 & 58 & 57 & 59 & 65 & 62 \\
\hline 5 . & Control & 62 & 60 & 61 & 68 & 69 & 69 \\
\hline & Mean & 57 & 58 & & 62 & 65 & \\
\hline & $\mathrm{LSD}_{0.05}$ & 2.1 & 1.9 & & 1.4 & 1.8 & \\
\hline & CV\% & 3.4 & 3.7 & & 3.3 & 3.8 & \\
\hline
\end{tabular}


Journal of Maize Research and Development (2016) 2 (1): 83-93

ISSN: 2467-9291 (Print), 2467-9305 (Online)

DOI: http://dx.doi.org/10.3126/jmrd.v2i1.16218

Table 6. Effect of different nitrogen application timings on plant height and ear height of maize for two consecutive years (2012/013 and 2013/014) at Rampur, Chitwan, Nepal

\begin{tabular}{|c|c|c|c|c|c|c|c|}
\hline \multirow[t]{3}{*}{$\mathrm{SN}$} & \multirow[t]{3}{*}{$\mathrm{N}$ application timings } & \multicolumn{2}{|c|}{ Plant height $(\mathrm{cm})$} & \multirow[t]{3}{*}{ Mean } & \multicolumn{2}{|c|}{ Ear height $(\mathrm{cm})$} & \multirow[t]{3}{*}{ Mean } \\
\hline & & 2012 & 2013 & & 2012 & 2013 & \\
\hline & & $/ 013$ & $/ 014$ & & $/ 013$ & $/ 014$ & \\
\hline 1 & $\begin{array}{l}60 \mathrm{~kg} \mathrm{~N} \mathrm{ha}^{-1} \text { basal application and } \\
60 \mathrm{~kg} \mathrm{~N} \mathrm{ha}^{-1} \text { at } 45 \text { DAS }\end{array}$ & 159 & 134 & 147 & 76 & 68 & 72 \\
\hline 2 & $\begin{array}{l}40 \mathrm{~kg} \mathrm{ha}^{-1} \text { basal, } 40 \mathrm{~kg} \mathrm{ha}^{-1} \\
\text { each at } 45 \text { and } 60 \text { DAS. }\end{array}$ & 152 & 148 & 150 & 75 & 73 & 74 \\
\hline 3 & $\begin{array}{l}30 \mathrm{~kg} \mathrm{ha}^{-1} \text { basal, } 30 \mathrm{~kg} \mathrm{~N} \\
\text { each at } 30,45 \text {, and } 60 \text { DAS }\end{array}$ & 158 & 145 & 152 & 77 & 71 & 74 \\
\hline 4 & $\begin{array}{l}30 \mathrm{~kg} \mathrm{~N} \mathrm{ha}^{-1} \text { each at } \\
30,45,60 \text {, and } 75 \mathrm{DAS}\end{array}$ & 161 & 144 & 153 & 76 & 74 & 75 \\
\hline \multirow[t]{4}{*}{5} & Control & 112 & 126 & 119 & 61 & 54 & 58 \\
\hline & Mean & 148 & 139 & & 73 & 68 & \\
\hline & $\mathrm{LSD}_{0.05}$ & 5.9 & 6.2 & & 4.09 & 5.2 & 3.2 \\
\hline & CV\% & 7.1 & 6.59 & & 7.65 & 7.2 & \\
\hline
\end{tabular}

Table 7. Effect of different nitrogen application timings on grain yield of maize for two consecutive years (2012/013 and 2013/014) at Rampur, Chitwan, Nepal

\begin{tabular}{|c|c|c|c|c|}
\hline \multirow[t]{2}{*}{$\mathrm{SN}$} & \multirow[t]{2}{*}{ Treatments } & \multirow{3}{*}{$\frac{2012 / 013}{3890}$} & \multirow{3}{*}{$\begin{array}{l}2013 \\
/ 014 \\
3737\end{array}$} & \multirow{2}{*}{$\begin{array}{c}\text { Grain } \\
\text { yield }\left(\mathrm{kg} \mathrm{ha}^{-1}\right)\end{array}$} \\
\hline & & & & \\
\hline 1 & $\begin{array}{l}60 \mathrm{~kg} \mathrm{~N} \mathrm{ha}^{-1} \text { basal application and } \\
60 \mathrm{~kg} \mathrm{~N} \mathrm{ha}^{-1} \text { at } 45 \mathrm{DAS}\end{array}$ & & & 3814 \\
\hline 2 & $\begin{array}{l}40 \mathrm{~kg} \mathrm{ha}^{-1} \text { basal, } 40 \mathrm{~kg} \mathrm{ha}^{-1} \\
\text { each at } 45 \text { and } 60 \text { DAS. }\end{array}$ & 3466 & 3567 & 3517 \\
\hline 3 & $\begin{array}{l}30 \mathrm{~kg} \mathrm{ha}^{-1} \text { basal, } 30 \mathrm{~kg} \mathrm{~N} \\
\text { each at } 30,45 \text {, and } 60 \text { DAS }\end{array}$ & 3844 & 3579 & 3712 \\
\hline 4 & $\begin{array}{l}30 \mathrm{~kg} \mathrm{~N} \mathrm{ha}^{-1} \text { each at } 30,45,60 \text {, } \\
\text { and } 75 \mathrm{DAS}\end{array}$ & 3828 & 3993 & 3911 \\
\hline \multirow[t]{4}{*}{5} & Control & 2857 & 2744 & 2801 \\
\hline & Mean & 3577 & 3524 & \\
\hline & $\mathrm{LSD}_{0.05}$ & 544 & 591 & \\
\hline & $\mathrm{CV} \%$ & 17.3 & 19.2 & \\
\hline
\end{tabular}
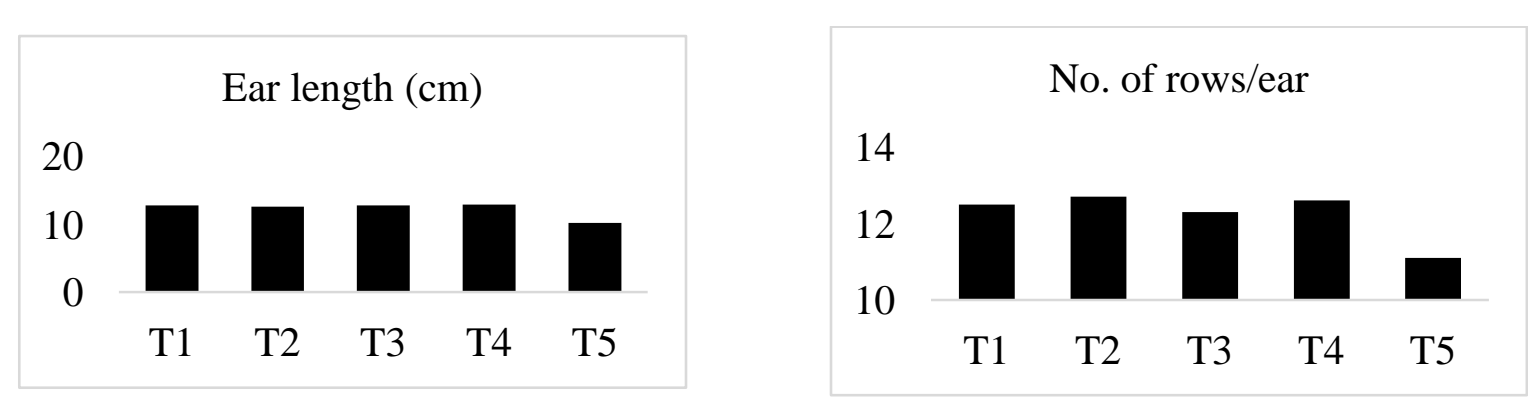

Figure 5. Combined response of different nitrogen application timings on ear length and no. of rows per ear of maize for two consecutive years (2012/013 and 2013/014) at Rampur, Chitwan, Nepal 

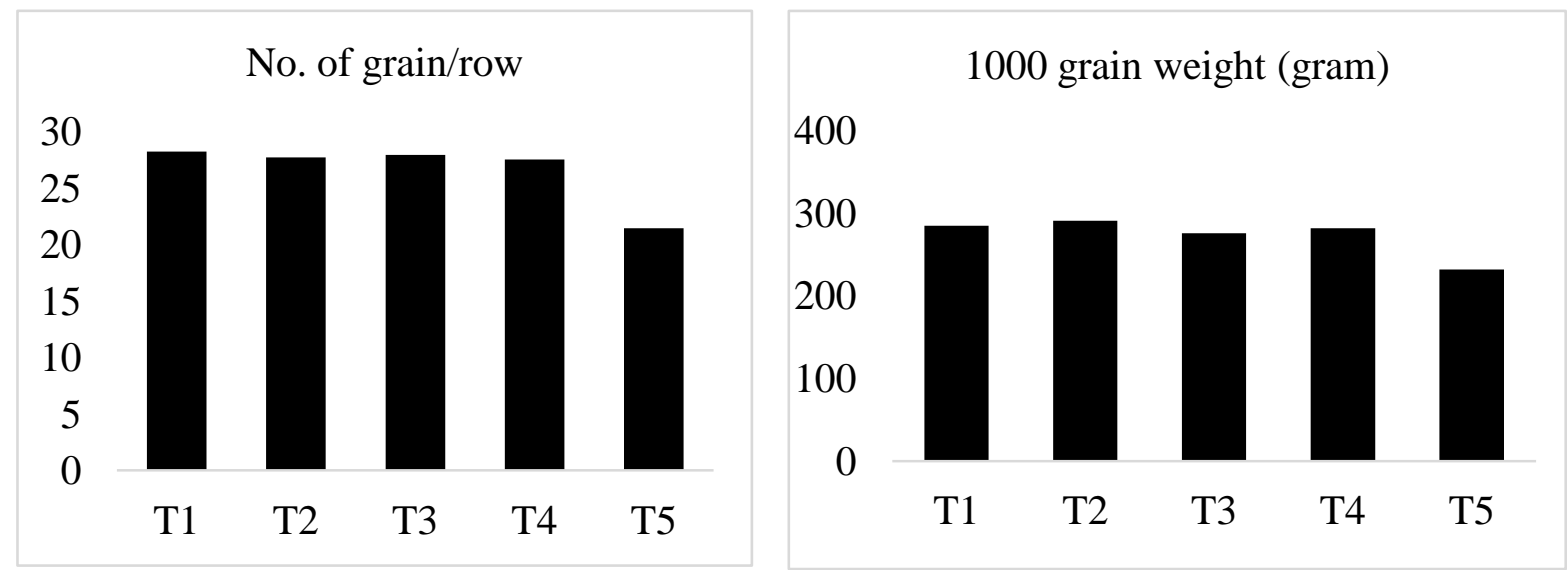

Figure 6. Combined response of different nitrogen application timings on number of grain per row and 1000-grain weight of maize for two consecutive years $(2012 / 013$ and 2013/014) at Rampur, Chitwan, Nepal

\section{Grain yield}

Grain yield significantly differed $(\mathrm{P}<0.001)$ due to growing seasons and fertilizer split applications. Significantly higher grain yield (3911 kg ha ${ }^{-1}$ ) was observed with $30 \mathrm{~kg} \mathrm{~N}^{-1}$ each at 30, 45, 60, and 75 DAS. Regarding the growing season, highest grain yield was observed in winter season (4393 kg ha-1) followed by spring (3791 kg ha'), and summer season (2468 $\mathrm{kg} \mathrm{ha}^{-}$ $\left.{ }^{1}\right)$, respectively. The result behind more grain yield in the winter season might be due to accumulation of more photosynthates in the cooler season because of lower respiration rates as described by Hatfield and Prueger et al.(2015). Similarly, mortality of pollen grain would also be less in the cooler season as compared to summer and spring season planting and lesser chance of unfilled grains in the ears. The minimum temperature in the coolest season at Chitwan is around 5-7 degree Celsius and there is very little chance of pollen freezing or chilling effect in this temperature, hence more filled grains as compared to summer and spring season could be expected as explained by Hatfield and Prueger (2014). Fabunmi et al. (2009) reported that N fertilizer application has variable maize yield response and concluded that application of $\mathrm{N}$ with splits produced significantly higher grain yield rather than basal application only. Research results have recommended different techniques to minimize $\mathrm{N}$ losses from different types of soils.

\section{CONCLUSION}

Maize can be successfully grown throughout the year in Chitwan and similar terai environments, however winter season planting is more favorable for higher yield. Around 20 percent and 80 percent more grain yield could be harvested in the winter season planting as compared to spring season and summer season planting. Likewise, for good harvest of grain yield 4 splits of $\mathrm{N}$ viz. application of $30 \mathrm{~kg} \mathrm{~N} \mathrm{ha}^{-1}$ each at 30, 45, 60, and 75 days after sowing respectively, would be more economical for achieving higher grain yield. 
Journal of Maize Research and Development (2016) 2 (1): 83-93

ISSN: 2467-9291 (Print), 2467-9305 (Online)

DOI: http://dx.doi.org/10.3126/jmrd.v2i1.16218

\section{ACKNOWLEDGEMENTS}

The authors are thankful to the technical staffs of NMRP who helped to accomplish field experiments of this study. Their special thanks go to Mr. Him Lal Bohara for his continuous effort on lab works and field data collections as well. They thank NMRP for providing research facilities including lab as well as field experimentation for this project.

\section{REFERENCES}

ABPSD. (2014). Agri-business promotion and statistical division, ministry for agriculture and cooperatives, Singhadarbar, Kathmandu, Nepal.

Adhikary, B.H., Sherchan D.P., \& Neupane, D.D. (2004). Effects of nitrogen levels on the production of maize (Zea mays L.) planted at varying densities in the Chitwan valleys. pp 216-219. In: Sherchan, D.P., Adhikari, K., Basta, B.K., and Paudel, D. Proceedings of the $22^{\text {nd }}$ national summer crops research workshop on maize research and production in Nepal, June 28-30, 2004, Nepal Agricultural Research Institute, NARC, Khumaltar, Lalitpur, Nepal.

Baral, B.R., Adhikari, P., \& Shrestha, J. (2015). Growth and yield response of hybrid maize (Zea mays L.) to phosphorus levels in sandy loam soil of Chitwan valley, Nepal. International Journal of Environmental Science, 4(2),147-156.

Baral, B.R., Adhikari, P., \& Shrestha, J. (2016). Productivity and Economics of Hybrid Maize (Zea mays L.) under different Fertilizer Doses in the Inner Terai Region of Nepal. Journal of AgriSearch, 3(1), 13-17

Carangal, V.R., Ali, S.M., Koble, A.F., \& Rinke, E.H. (1971). Comparison of S1 with testcross evaluation for recurrent selection in maize. Crop Science, 11, 658-661.

Fabunmi, T.O. (2009). Effect of different split appliacton of NPK fertilizer on growth and yield of maize and economic returns. Nigerian Agricultural Journal, 40, 1-5.

Hatfield, J.L., \& Prueger, J.H. (2015). Temperature extremes: Effect on plant growth and development. Weather and Climate Extremes, 10, 4-10.

Jat, M. L., Satyanarayana, T., Manundar, K., Parihar, C.M., Jat, S.L., Tetarwal, J.P., Jat, R.K., \& Saharawat, Y.S. (2013). Indian Journal of Fertilizer, 9 (4), 80-94.

K.C., G., Karki, T.B., Shrestha J., \& Achhami, B.B. (2015). Status and prospects of maize research in Nepal. Journal of maize research and development, 1(1), 1-9.

NMRP. (2015). Annual Report of National Maize Research Program Rampur Chitwan Nepal

OSU. (2016) Oklahoma State University. Information on world maize production. Retrieved from http://nue.okstate.edu/Crop_Information/World_Maize_Production.htm

Saseendran, S.A., Neilson, D.C., Ma L., Ahuja, L.R., \& Halvorson, A.D. (2004). Modeling nitrogen management effects on winter wheat production using RZWQM and CERESWheat. Agronomy Journal, 96 (3), 615-630.

Sherchan D.P., Neupane, D.D., Uprety, R., Adhikary, B.H., \& Maskey, S.L. (2004). Effects of micronutrients on grain production and improving quality of maize in acidic soils of the Chitwan valley. pp 193-197. In: Sherchan, D.P., Adhikari, K., Basta, B.K., \& Sherchan, D. Proceedings of the $22^{\text {nd }}$ National summer crops research workshop on maize research and production in Nepal, held in June 28-30, (2004), at Nepal Agricultural Research Institute, NARC, Khumaltar, Lalitpur, Nepal. 
Shrestha, J., Koirala, K., Katuwal, R., Dhami, N., Pokhrel, B., Ghimire, B., Prasai, H., Paudel, A., Pokhrel, K., \& KC, G. (2015). Performance evaluation of quality protein maize genotypes across various maize production agro ecologies of Nepal. Journal of Maize Research and Development,1(1), 21-27. doi:http://dx.doi.org/10.3126/jmrd.v1i1.14241 